\title{
Camallanus maculatus n. sp. (Nematoda: Camallanidae) in an ornamental fish Xiphophorus maculatus (Osteichthyes: Poeciliidae) cultivated in São Paulo State, Brazil
}

[Camallanus maculatus $n$. sp. (Nematoda: Camallanidae) em peixe ornamental Xiphophorus maculatus (Osteichthyes: Poeciliidae) cultivado no estado de São Paulo, Brasil]

\author{
M.L. Martins ${ }^{1}$, F. Garcia ${ }^{2}$, R.S. Piazza ${ }^{1}$, L. Ghiraldelli ${ }^{1}$ \\ ${ }^{1}$ Departamento de Aqüicultura - UFSC \\ Caixa Postal 476 \\ 88040-900 - Florianópolis, SC \\ ${ }^{2}$ Pólo Regional do Noroeste Paulista, APTA - Instituto de Pesca - Votuporanga, SP
}

\begin{abstract}
The present study describes Camallanus maculatus n. sp. (Nematoda: Camallanidae) from Xiphophorus maculatus (Osteichthyes: Poecilidae) collected in an ornamental fish farm in São Paulo State, Brazil. Thirty-three out of 40 examined fish were parasitized (82\% prevalence) with mean intensity of 2.8 (1-20).

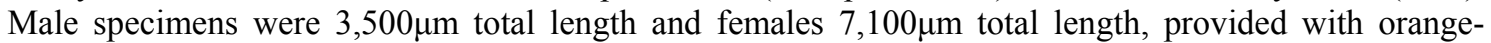
brown buccal capsule and two developed tridents. Males showed two unequal spicules, gubernaculum absent and females with vulva situated in the middle of the body. The main characteristics were the sleekly longitudinal ridges in the buccal capsule in both sexes, enlargement at the anterior end of the smaller spicule, the number of genital papillae, longer muscular and glandular portion of esophagus and round tail in female.
\end{abstract}

Keywords: fish, Xiphophorus maculatus, nematode, prevalence, Camallanus maculatus n. sp.

\section{RESUMO}

Descreve-se Camallanus maculatus n. sp. (Nematoda: Camallanidae) em Xiphophorus maculatus (Osteichthyes: Poecilidae) capturado em uma piscicultura ornamental no estado de São Paulo. De 40 peixes examinados, 33 estavam parasitados (prevalência de 82\%) cuja intensidade média foi de 2,8 (1-

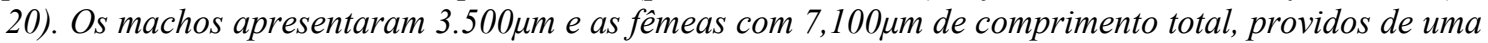
cápsula bucal laranja-castanho e dois tridentes. Observaram-se machos com espículos desiguais, gubernáculo ausente e fêmeas com vulva situada na metade do corpo. As principais características foram as estrias longitudinais lisas em cada valva da cápsula bucal em ambos os sexos, o espículo menor com alargamento na extremidade anterior, o número de papilas genitais, as porções muscular e glandular do esôfago longas e a cauda longa e arredondada na fêmea.

Palavras-chave: peixe, Xiphophorus maculatus, nematóide, prevalência, Camallanus maculatus $n . s p$.

\section{INTRODUCTION}

There is much profitable information concerning ornamental fish industry, one of them come from Evans and Lester (2001), who pointed out that it is estimated at 900 million dollars. National and international transport of fish contributes on

Recebido em 27 de outubro de 2005

Aceito em 13 de agosto de 2007

E-mail: mlaterca@cca.ufsc.br

Apoio: CAPES, CNPq parasites dissemination not only in ornamental, but also in native fish.

The presence of parasites in several ornamental fish species is mentioned by (Moravec et al., 1999) in Germany, Australia (Evans and Lester, 2001), Korea (Kim et al., 2002) and Brazil (Martins et al., 2007). Nematodes of the genus Camallanus Railliet and Henry, 1915, are widely distributed over the 
world and, in Brazil, Camallanus acaudatus and Camallanus tridentatus were found in Osteoglossum bicirrhosum and Arapaima gigas by Ferraz and Thatcher (1990). They could be seen into reared and native fish intestines (Amin, 1978; Baker, 1979; Ferraz and Thatcher, 1990; Lakshimi et al., 1990; Moravec 1994; Torres et al., 1991; Moravec, 1994; Martins et al., 2007). Their prevalence may reach $83.3 \%$ for both salmonids (Torres et al., 1990) and Poecilia reticulata (Kim et al., 2002) and 2.6\% in Xiphophorus maculatus from ornamental fish in Florianópolis-SC (Piazza et al., 2006). This ornamental fish has a great economical importance to Brazil, since it can be found anywhere and it is very well traded.

This study describes a new species of Camallanus found during a parasitological fauna survey of Xiphophorus maculatus Günther, 1866.

\section{MATERIAL AND METHODS}

Forty specimens of $X$. maculatus (Osteichthyes: Poeciliidae) weighting $0.50 \pm 0.1 \mathrm{~g}$ were collected from an ornamental fish farm in Araraquara-SP, Brazil, and also examined to find out if there were any nematodes. As the answer was affirmative, the researchers removed the nematodes carefully from fish intestines to fix them in $\mathrm{AFA}$, at $65^{\circ} \mathrm{C}$ for posterior preservation in $70 \%$ alcohol with $5 \%$ glycerine. Eighteen males and 23 females were studied after dehydration and cleared in Amann lactofenol, acetic acid or glycerine afterwards the drawings were prepared in camera lucida. Twenty larvae were measured from the studied females as well as identified according to Chabaud (1975) and Moravec (1973, 1994). Specimens deposited at the Helminthological Collection of Oswaldo Cruz Institute ${ }^{1}$. Holotype male, allotype female and paratypes (CHIOC n. 35283).

\section{RESULTS AND DISCUSSION}

Figure 1 (1-10) shows details of a male of Camallanus maculates n.sp. from $X$. maculatus.

In order to observe the morphology of medium sized nematodes, smooth cuticle and red colour in life were observed, but not cervical papillae. It

${ }^{1}$ Av. Brasil 4365, 21045-900, Rio de Janeiro, Brazil was also registered that their mouth opening was surrounded by two pairs of papillae and four sclerotic plates. The anterior end was provided with a large orange-brown buccal capsule with two sclerotic lateral valves, a short basal ring and two developed tridents, which slightly exceeded the basal ring. Internal surface of each valve, supported by sleekly longitudinal ridges, varied on numbers for both sexes. Each valve had a pair of brown thickenings on its anterior surface.

This trial also aimed at observing the oesophagus that is divided in two parts, the anterior and posterior muscular portions. From the analysis, the first one is slightly smaller than the second portion. There is another important issue, the opening of glandular oesophagus into intestine, provided by valves. Nevertheless, it was difficult to visualize the excretory pore, situated just after nerve ring that encircles the anterior portion of muscular oesophagus.

Males presented two different spicules, but their gubernaculum was absent. On the other hand, females had their vulvas in the middle of their bodies, indicating that they are viviparous (Fig. 1-10).

The mouth of the male had two posterior directed brown chitinous tridents, with three prongs each, described as a 90+7 (80-100) $\mu \mathrm{m}$ long middle prong of tridents and two lateral prongs that were $81 \pm 3(80-90) \mu \mathrm{m}$ long. Internal surface of valves was provided by 26 to 28 longitudinal ridges while spicules were different, simple and pointed to the posterior end. The small spicule was thin and provided by an enlargement. The caudal alae was narrowed as well as provided by pedunculated papillae with seven pairs of preanal and six pairs of postanal. The first three pairs were closed to one another as they were all together. The fifth pair of postanal papilla was larger than the others (see Fig. 1.8). According to the lateral view, when the cloacae region was surrounded, it could be seen two transversal structures, two pairs of sessile papillae (adanal) and a ventral flexed tail (Table 1).

Females also presented two posterior directed brown chitinous tridents, with three prongs each, described as a 135 $\pm 7(130-140) \mu \mathrm{m}$ long middle prong of tridents and two lateral prongs that were $117 \pm 10(110-124) \mu \mathrm{m}$ long. The internal surface of valves was provided by 30 to 32 longitudinal ridges. 


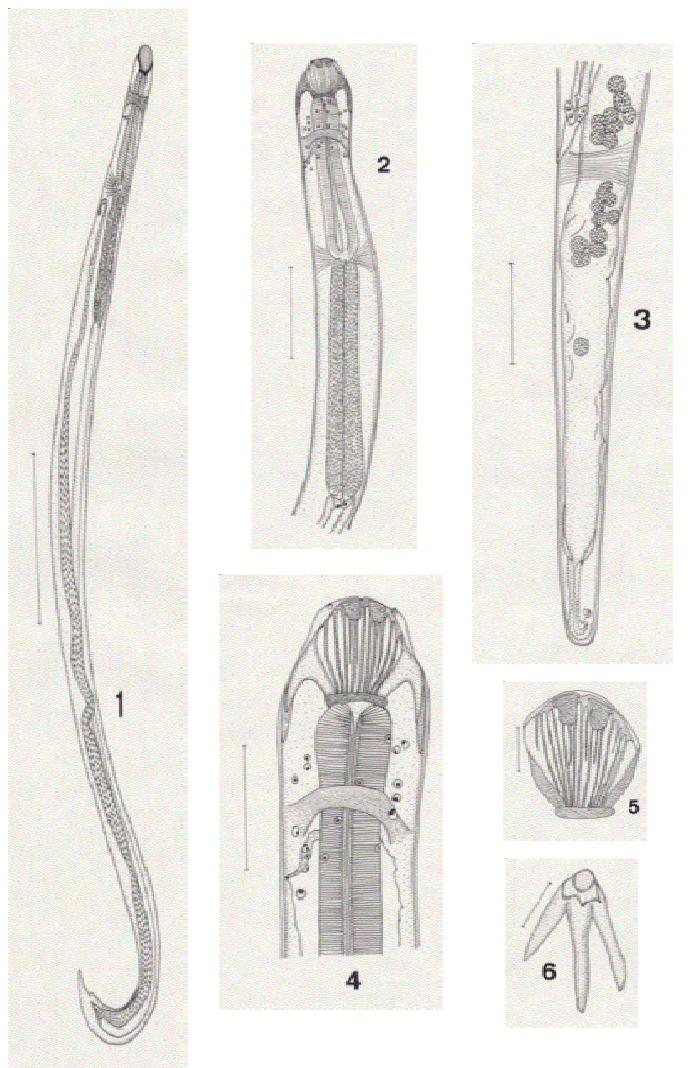

Figure 1. Male of Camallanus maculatus n. sp. from

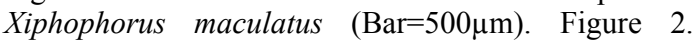
Anterior extremity of male showing oesophagus, lateral view $(B a r=200 \mu \mathrm{m})$. Figure 3. Lateral view of female tail $(\mathrm{Bar}=200 \mu \mathrm{m})$. Figure 4. Anterior extremity of male with detail of excretory pore, lateral view $(\mathrm{Bar}=100 \mu \mathrm{m})$. Figure 5. Buccal capsule of female, lateral view $(\mathrm{Bar}=50 \mu \mathrm{m})$. Figure 6. Trident of female, dorsal view $(\mathrm{Bar}=50 \mu \mathrm{m})$.

During the study of their reproductive organs, it was observed that muscular vagina was posterior directed from vulva. Vagina vera, measured in eight specimens, was $57 \pm 6(50-72) \mu \mathrm{m}$ long and vagina uterine, from eight specimens, was 212 23 (180264) $\mu \mathrm{m}$ long. Uterus was posterior directed to the end of the tail. In order to measure their eggs, thirty of them presented $34 \pm 2(30-38) \mu \mathrm{m}$ of diameter. From dissected females, the larvae into the uterus measured $390 \pm 7(380-400) \mu \mathrm{m}$ long by $20 \pm 2$ (1824) $\mu \mathrm{m}$ width as well as a rounded tail (Table 1 ).

The high prevalence rate from this study was similar to Camallanus oxycephalus Ward and Magath, 1916 (Stromberg and Crites, 1975), Camallanus sp. (Lyan and Seng, 1979), Camallanus corderoi Torres, Teuber and Miranda, 1990 (Torres et al., 1990) and Camallanus cotti Fujita, 1927 (Font and Tate, 1994; Rigby et al.,

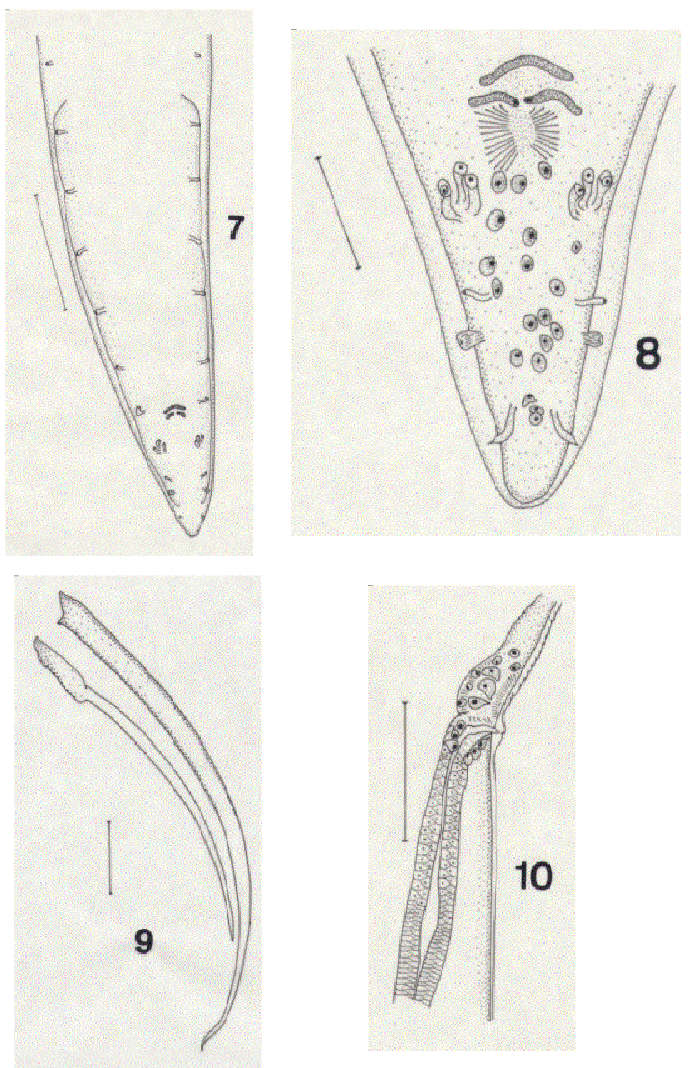

Figure 7. Posterior end of male showing papillae and caudal alae, ventral view $(\mathrm{Bar}=100 \mu \mathrm{m})$. Figure 8 . Posterior end of male with details of the postanal papillae (note the shape of the fifth pair), ventral view $(\mathrm{Bar}=30 \mu \mathrm{m})$. Figure 9. Spicules $(\mathrm{Bar}=20 \mu \mathrm{m})$. Figure 10. Lateral view of vulva $(B a r=100 \mu \mathrm{m})$.

1997; Kim et al., 2002). On the other hand, the mean intensity was higher than the one registered by Torres et al. (1991), in salmonids.

Aiming at comparing the described species, the nematodes were arranged according to the presence of tridents, two spicules and longitudinal ridges shape, as these main characteristics were suggested by Moravec (1973) and Gupta and Verma (1978). Measurements of both sexes were different in total length, buccal capsule length and width, number of longitudinal ridges, muscular and glandular oesophagus length, number of genital papillae and spicules length from Camallanus longicaudatus Moravec, 1973; Camallanus kirandensis Amin, 1978; Camallanus ancylodirus Baker, 1979; Camallanus tholukodensis Lakshimi, Rao and Shyamasundari, 1990. 
The present specimens differ from Camallanus lacustris Zoega, 1776 (Moravec, 1994) due to the greater number of longitudinal ridges in buccal capsule, the highest measures of tridents in both sexes, the absence of mucrons on tails of females, shorter glandular oesophagus, nerve ring position Table 1. Measurements of Camallanus maculatus Brazil

\begin{tabular}{|c|c|c|}
\hline $\begin{array}{c}\text { Characteristic or } \\
\text { features }\end{array}$ & Male & Female \\
\hline Total length & $3,500 \pm 363(2,700-4,100)$ & $7,100 \pm 1461(4,400-9,020)$ \\
\hline Width & $168+31(80-204)$ & $298 \pm 73(163-450)$ \\
\hline Buccal capsule L & $79 \pm 4(70-84)$ & $131 \pm 43(110-320)$ \\
\hline Buccal capsule W & $80 \pm 9(70-96)$ & $137 \pm 43(116-324)$ \\
\hline Basal ring $\mathrm{L}$ & $11 \pm 5(4-20)$ & $16 \pm 7(4-40)$ \\
\hline Basal ring $\mathrm{W}$ & $52 \pm 5(40-60)$ & $75 \pm 16(20-100)$ \\
\hline Muscular Oesophagus L & $342 \pm 49(256-400)$ & $521 \pm 60(440-656)$ \\
\hline Muscular Oesophagus W & $82 \pm 16(40-120)$ & $91 \pm 11(72-120)$ \\
\hline Glandular Oesophagus L & $452+54(392-560)$ & $610+54(496-680)$ \\
\hline Glandular Oesophagus W & $78+15(32-96)$ & $95+15(64-120)$ \\
\hline Nerve ring ${ }^{1}$ & $141+41(80-200)$ & $236+44(120-280)$ \\
\hline Excretory pore $^{1}$ & $250+42(240-270)$ & $380+72(360-400)$ \\
\hline Large spicule L & $148+23(107-204)$ & - \\
\hline Large spicule $\mathrm{W}$ & $11 \pm 2(8-16)$ & - \\
\hline Small spicule L & $99 \pm 11(80-124)$ & - \\
\hline Small spicule W & $6 \pm 2(3-10)$ & - \\
\hline Caudal alae L & $323+57(230-390)$ & - \\
\hline Caudal alae W & $12 \pm 4(4-18)$ & - \\
\hline Testis L & $3,000+390(2,400-3,900)$ & - \\
\hline Testis W & $71 \pm 17(40-96)$ & - \\
\hline Testis reflexion $^{2}$ & $665 \pm 203(448-1,040)$ & - \\
\hline Vulva $^{1}$ & - & $3,900+856(2,500-5,100)$ \\
\hline Tail & $115+8(92-120)$ & $900+180(700-1,300)$ \\
\hline
\end{tabular}

L: length; W: width; ${ }^{1}$ Distance of the structure from anterior extremity; ${ }^{2}$ Distance of the testis reflexion to the anterior extremity. Averages are in micrometers followed by standard deviation and range in parentheses

The present nematodes may be distinguished from $C$. testudineusi by a greater number of longitudinal ridges and their sleekly appearances, smaller buccal capsule and basal ring, shorter spicules, number of genital papillae and also by an enlargement at the anterior end of the smaller spicule. Also, they differ from C. cotti (Moravec and Sey, 1988; Rigby et al., 1997) by nerve ring position, testis flexure more distant from anterior end, shorter caudal alae, the highest measures of spicules in males and once more by an enlargement at the anterior extremity of the smaller spicule. Moreover, the present specimens can also be distinguished by their greater number of longitudinal ridges, excretory pore position and trident prongs, which are longer than those ones observed in $C$. cotti in both sexes. and longer tail in females. However, similar features were observed by analysing Camallanus testudineusi Gupta and Verma, 1978, C. cotti (Moravec and Sey, 1988; Rigby et al., 1997); $C$. corderoi (Torres et al., 1990) and Camallanus truncatus Rudolphi, 1814 (Moravec, 1971, 1994).

from Xiphophorus maculatus in São Paulo State, 
Despite the similarity of the present material with $C$. anabantis measurements from De and Ghosh, 1989, important characteristics as smaller spicules length and shape, absence of mucrons in male, female tail and number of genital papillae were the main differences. By analyses, $C$. kilasirii De and Ghosh, 1989 and C. carangis Rigby, Adamson and Deardorff, 1998, found out that these nematodes differed not only due to mucrons absence, but also because of genital papillae number, the position of nerve ring and excretory pore, the shape and length of spicules and longitudinal ridges in buccal capsule.
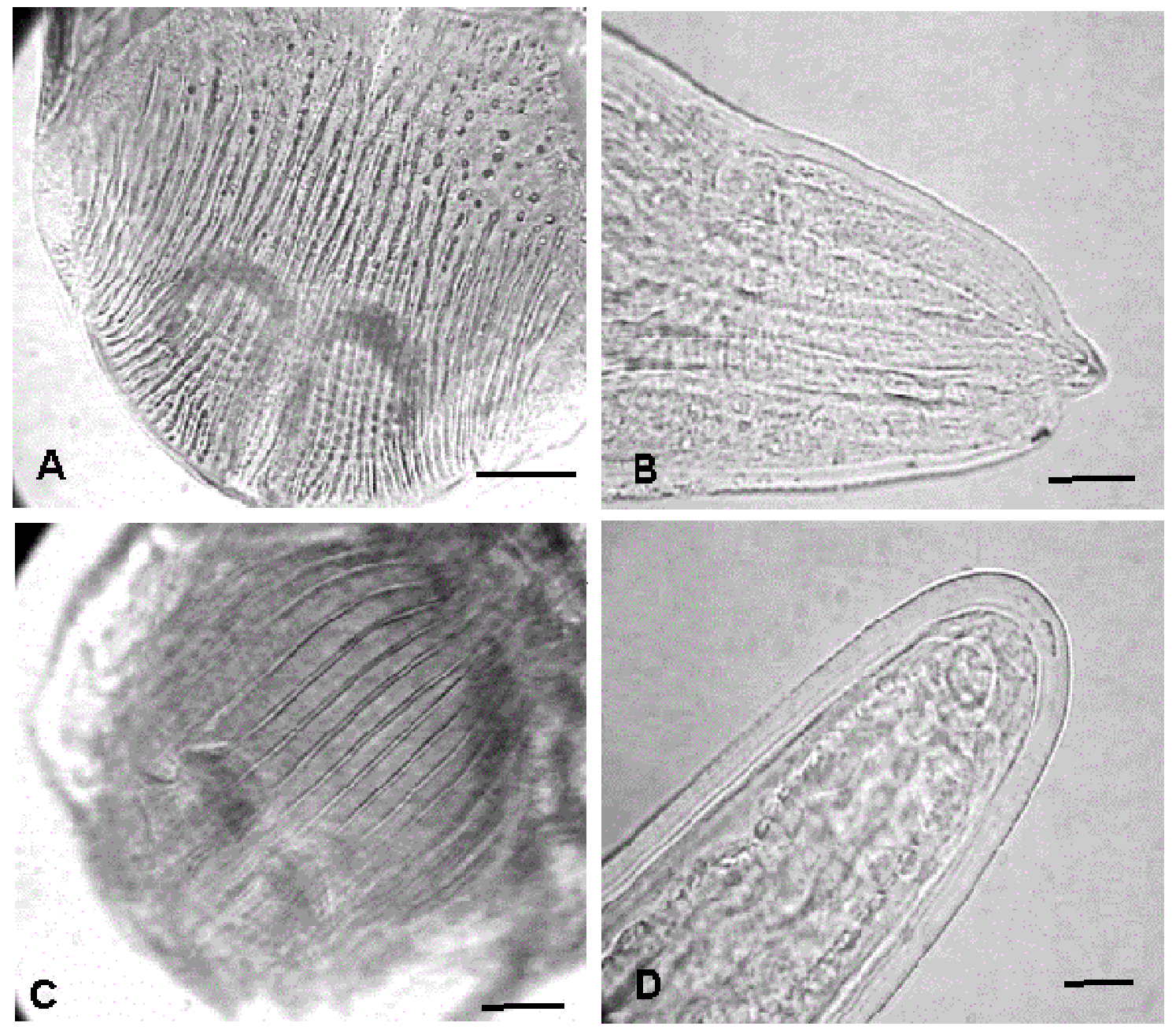

Figure 11. Shape of the longitudinal ridges in the buccal capsule and female tail of Camallanus corderoi Torres, Teuber and Miranda, 1990 from Percichthys trucha (A-B) and Camallanus maculatus n. sp. from Xiphophorus maculatus $(\mathrm{C}-\mathrm{D})$. Bar $=20 \mu \mathrm{m}$. 
The smaller spicule had an enlargement in its anterior end and the tail end is longer and in the females rounded when compared to shorter and conical tail of $C$. corderoi. Other results regarding spicule length showed significantly shorter dimensions when compared to those already shown in other researches. Once more, it differed from $C$. corderoi by a shorter muscular and glandular portion of oesophagus that was easily confirmed by analysing those specimens. Finally, the present description differed from Camallanus acaudatus Ferraz and Thatcher, 1990, described in Brazil, by the presence of two spicules, the highest measurements of body length, buccal capsule, glandular oesophagus, excretory pore position, significantly shorter caudal alae, as well as number of genital papillae and tail in males. When compared to Camallanus tridentatus Drasche, 1884 (Ferraz and Thatcher, 1990), these specimens had shown larger buccal capsule, greater number of longitudinal ridges, number of post-anal papillae and two spicules in males. Almost all measurements differed, but basal ring and excretory pore in $C$. acaudatus and $C$. tridentatus females. Important differences, that must be commented, are the sub-terminal anus in C. acaudatus and bifurcated tail in $C$. tridentatus females, which were very different from this description.

At last, by the differences observed in buccal capsule concerning longitudinal ridges and smaller spicule shapes, excretory pore, nerve ring position, muscular, glandular oesophagus, spicules length, number of genital papillae, caudal alae length in males and several characteristics of females such as their tails end, the authors suggest that there is a new species and a new host for camallanid nematode in Brazil.

\section{ACKNOWLEDGEMENTS}

The authors thank CNPq for financial support; Dr. Patricio Torres (Instituto de Parasitología, Universidad Austral de Chile, Valdivia, Chile) for sending the specimens of Camallanus corderoi for comparison with our material. To Aristides Manso Figueiredo Júnior (Brejo Grande Ltda fish farm) for fish donation and to make possible the development of the work in the facilities and to Ana Maria Vasconcelos for correction of the manuscript idiom.

\section{REFERENCES}

AMIN, O.M. Intestinal helminths of some Nile fishes near Cairo, Egypt with redescriptions of Camallanus kirandensis Baylis 1928 (Nematoda) and Bothriocephalus aegytiacus Rysavy and Moravec 1975 (Cestoda). J. Parasitol., v.64, p.93-101, 1978.

BAKER, M.R. Redescription of Camallanus ancylodirus Ward and Magath 1916 (Nematoda: Camallanidae) from freshwater fishes of North America. J. Parasitol., v.65, p.389-392, 1979.

CHABAUD, A.G. CIH keys to the nematode parasites of vertebrates. 3. Keys to genera of the Order Spirurida. Part I. In: ANDERSON, R.C.; CHABAUD, A.G.; WILlMOTT, S. (Eds). England: Commonwealth Agricultural Bureaux, 1975. 27p.

EVANS, B.B.; LESTER, R.J.G. Parasites of ornamental fish imported to Australia. Bull. Eur. Assoc. Fish Pathol., v.21, p.51-55, 2001.

FERRAZ, E.; THATCHER, V.E. Camallanus acaudatus sp. n. (Nematoda: Camallanidae) e uma descrição do macho de Camallanus tridentatus (Drasche, 1884), parasitas de peixes da Amazônia Brasileira. Amazoniana, v.11, p.135-145, 1990.

FONT, W.F.; TATE, D.C. Helminth parasites of native hawaiian freshwater fishes: an example of extreme ecological isolation. J. Parasitol., v.80, p.682-688, 1994.

GUPTA, S.P.; VERMA, S.L. On four new species of the genus Camallanus (Family: Camallanidae Railliet et Henry, 1915) from freshwater fishes of Lucknow. Rev. Parasitol., v.39, p.117-129, 1978.

KIM, J.-H.; HAYWARD, C.J.; HEO, G.-J. Nematode worm infections (Camallanus cotti, Camallanidae) in guppies (Poecilia reticulata) imported to Korea. Aquaculture, v.205, p.231235, 2002.

LAKSHIMI, I.R.; RAO, K.H.; SHYAMASUNDARI, K. Camallanus tholukodensis sp. n. from the freshwater cat fish, Mystus seenghala (Sykes) of Tholukodu (Andhra Pradesh). Acta Parasitol. Pol., v.35, p.37-44, 1990.

LYAN, C.G.; SENG, L.T. Parasites of fishes from Sungai Pinang and Sungai Teluk Bahang, 
Pulau Pinang, Malaysia. Mal. Nat. J., v.32, p.247-251, 1979.

MARTINS, M.L.; GHIRALDELLI, L.; GRACIA, F. et al. Experimental infection in Notodiaptomas sp. (Crustacea: Calanoida) with larvae of Camallanua sp. (Nematoda: Camallanidae). Arq. Bras. Med. Vet. Zootec., v.59, p.382-386, 2007.

MORAVEC, F. Nematodes of fishes in Czechoslovakia. Acta Sc. Nat. Brno, v.5, p.1-49, 1971.

MORAVEC, F. On the nematode Camallanus longicaudatus sp. n. from the Nile fish, Labeo horie Heck. Rev. Zool. Bot. Afr., v.87, p.165-173, 1973.

MORAVEC, F. Parasitic nematodes of freshwater fishes of Europe. Czech Republic: Kluwer Academic Publishers, 1994. 473p.

MORAVEC, F.; SEY, O. Nematodes of freshwater fishes from North Vietnam. Part I. Camallanoidea and Habronematoidea. Vest. Cs. Spolec. Zool., v.52, p.128-148, 1988.

MORAVEC, F.; WOLTER, J.; KÖRTING, W. Some nematodes and acanthocephalans from exotic ornamental freshwater fishes imported into Germany. Folia Parasitol., v.46, p.296-310, 1999.
PIAZZA, R.S; MARTINS, M.L; GHIRALDELLI, L. et al. Parasitic diseases of freshwater ornamental fishes commercialized in Florianópolis, Santa Catarina, Brazil. Bol. Inst. Pesca, v.32, p.51-57, 2006.

RIGBY, M.C.; FONT, W.F.; DEARDORFF, T.L. Redescription of Camallanus cotti Fujita, 1927 (Nematoda: Camallanidae) from Hawaii. $J$. Parasitol., v.83, p.1161-1164, 1997.

STROMBERG, P.C.; CRITES, J.L. Population biology of Camallanus oxycephalus Ward and Magath, 1916 (Nematoda: Camallanidae) in white bass in Western Lake Erie. J. Parasitol., v.61, p.123-132, 1975.

TORRES, P.; TEUBER, S.; MIRANDA, J.C. Parasitismo en ecosistemas de agua dulce de Chile. 2. Nematodos para sitos de Percichthys trucha (Pisces: Serranidae) com la descripción de una nueva especie de Camallanus (Nematoda: Spiruroidea). Stud. Neotrop. Fauna Environm., v. 25, p.111-119, 1990 .

TORRES, P.; CABEZAS, X.; ARENAS, J. et al. Ecological aspects of nematode parasites of introduced salmonids from Valdivia river basin, Chile. Mem. Inst. Oswaldo Cruz, v.86, p.115$122,1991$. 